УДК 504.75.05: 504.3.054 ](477.46)

\author{
Т. П. Гончаренко, к.х.н., доиент, \\ e-mail: t.p.g@inbox.lv \\ Л. І. Жицька, к.б.н., доиент \\ e-mail: zhytska 1yudmila@ukr.net \\ Черкаський державний технологічний університет \\ б-р Шевченка, 460, Черкаси, 18006, Україна
}

\title{
АНАЛІЗ І ОЦІНКА РИЗИКІВ ЗАХВОРЮВАННЯ НАСЕЛЕННЯ ЗАЛЕЖНО ВІД ЯКОСТІ АТМОСФЕРНОГО ПОВІТРЯ В МІСТІ ЧЕРКАСИ У 2017 РОЦІ
}

Проведено аналіз статистичної інформаиї̈ про об'єми викидів пересувних та стаціонарних джерел забруднення атмосферного повітря. Дано оцінку комплексного впливу викидів шкідливих речовин на якість повітряного басейну та здоров'я населення міста. Розглянуто причини, шо сприяють накопиченню забруднюючих речовин. Розраховано рівні ризику захворюваності населення м. Черкаси, що проживає у місиях небезпечного забруднення атмосферного повітря.

Ключові слова: атмосферне повітря, викиди, концентрачія, забруднююча речовина, здоров'я, ризик, Черкаси.

Постановка проблеми. Одним із важливих об'єктів навколишнього природного середовища $\epsilon$ атмосферне повітря. Стійкість біосфери залежить від його чистоти. Забруднення біосфери впливає на рослини, тварини, людей, будови, обладнання та різні матеріали. Повітря, яким ми дихаємо, являє собою фізичну суміш газів, які становлять атмосферу. Повітря має постійні складові атмосфери й непостійну кількість різних домішок природного й антропогенного походження. Під впливом антропогенної діяльності людини до атмосферного повітря потрапляють різного роду забруднювачі, внаслідок чого формуються негативні тенденції до виникнення надзвичайних ситуацій, погіршення умов життедіяльності і зростання захворюваності населення.

Здоров'я людини визначається взаємодією низки таких факторів: спадковість, спосіб життя, наявність шкідливих звичок, соціально-економічне і психологічне благополуччя, доступність медичного обслуговування, умови життєдіяльності та якість навколишнього середовища [1]. Для людини несприятливе забруднення будь-якого з компонентів природного середовища, 3 яким вона контактує, при цьому можуть уражатися всі iii системи й органи. 3 погляду здоров'я людини особливу роль відіграє атмосфера. Контакти людини з забруднювачами середовища через повітря відбуваються частіше, ніж через воду, рослини та інші його компоненти [2, с. 278].
На сьогоднішній день оцінка якості та безпеки повітря розраховується не тільки порівнянням рівня забруднення 3 гранично допустимими значеннями концентрації викиду, а й із позицій концепції екологічного ризику. Екологічний ризик - можливість виникнення не сприятливих для життєдіяльності суспільства обставин і ситуацій, зумовлених антропогенними чи природними факторами і впливами [3, с. 390].

Дуже важливим $є$ визначення ризику для здоров'я населення при сучасному стані забруднення атмосферного повітря, бо при виникненні надзвичайних ситуацій (аварій, пожеж, вибухів) рівень небезпеки для населення і природних екосистем зростає в кілька разів.

Аналіз останніх досліджень і публікацій. Черкаси - обласний центр в Україні, промисловий центр Центрального економічного району. Місто розташоване на правому березі Кременчуцького водосховища, створеного у середній течії Дніпра, та простяглось на 17 км уздовж берега. Клімат міста $є$ помірно континентальним з м'якою зимою і теплим літом. Як показав аналіз літературних джерел $[4,5]$, метеорологічний режим в м. Черкаси не сприяє розсіюванню домішок як від високих джерел емісії, так і низьких. До основних метеорологічних чинників, що визначають рівень забруднення в місті, належать температурні інверсії, швидкість та напрям вітру, бризова циркуляція повітря. Для м. Черкаси характерні вітри південного напрямку, які 
мають високий відсоток повторюваності та здійснюють перенесення забруднюючих речовин від потенційно-небезпечних об'єктів ПАТ «Азот» $\mathrm{i}$ ПАТ «Черкаське хімволокно» на всю територію міста. А періоди слабкої швидкості вітру (0-1 м/с) та наявності стійких інверсій, які досить часто спостерігаються в місті (до $20 \%$ за рік, влітку в 1,5-2 рази біль- ше), створюють небезпечні умови накопичення шкідливих домішок і від низьких джерел, зокрема автотранспорту.

Аналіз статистичних матеріалів показує, що забруднення атмосферного повітря у місті відбувається за рахунок стаціонарних (40-70\% від загальної кількості викидів) та пересувних (60-30\%) джерел (табл. 1) [6, 7, 8].

Таблиця 1

Динаміка викидів в атмосферне повітря м. Черкаси

\begin{tabular}{|c|c|c|c|c|c|}
\hline \multirow[b]{3}{*}{ Роки } & \multicolumn{3}{|c|}{ Викиди в атмосферне повітря, тис. т } & \multirow{3}{*}{$\begin{array}{c}\text { Щільність } \\
\text { викидів у } \\
\text { розрахунку } \\
\text { на один } \\
\text { км², кг }^{2}\end{array}$} & \multirow{3}{*}{$\begin{array}{c}\text { Обсяги } \\
\text { викидів у } \\
\text { розрахунку } \\
\text { на одну } \\
\text { особу, кг }\end{array}$} \\
\hline & \multirow[b]{2}{*}{ Всього } & \multicolumn{2}{|c|}{ У тому числі } & & \\
\hline & & $\begin{array}{c}\text { стаціонарними } \\
\text { джерелами }\end{array}$ & $\begin{array}{c}\text { пересувними } \\
\text { джерелами }\end{array}$ & & \\
\hline 2000 & 36,907 & 16,821 & 20,086 & 527,2 & 120,1 \\
\hline 2010 & 48,707 & 32,277 & 16,430 & 695,8 & 169,1 \\
\hline 2012 & 51,989 & 35,736 & 16,253 & 666,5 & 181,4 \\
\hline 2013 & 55,546 & 39,893 & 15,653 & 712,1 & 194,1 \\
\hline 2014 & 50,652 & 36,389 & 14,263 & 649,4 & 177,2 \\
\hline 2015 & 42,319 & 29,826 & 12,493 & 542,6 & 148,5 \\
\hline 2016 & & 23,845 & * & 305,7 & 84,2 \\
\hline
\end{tabular}

* За даними Головного управління статистики у Черкаській області, у 2016 р. розрахунки щодо обсягів викидів забруднюючих речовин від пересувних джерел забруднення не проводились

Протягом останніх років перелік основних забруднюючих речовин атмосферного повітря міста залишається майже без змін. Динаміку викидів стаціонарними джерелами в атмосферне повітря м. Черкаси, в тому числі за найпоширенішими речовинами (пил, діок- сид сірки, діоксид азоту, оксид вуглецю) подано в табл. 2. Табл. 2 показує, що у 2016 р. знизилися викиди пилу (майже в 2000 разів) та діоксиду сірки (в 2 рази), а викиди діоксиду азоту та оксиду вуглецю збільшилися в 1,1 разу $[6,7,8]$.

Таблиця 2

Динаміка викидів стаціонарними джерелами в атмосферне повітря м. Черкаси,

в тому числі за найпоширенішими речовинами

(пил, діоксид сірки, діоксид азоту, оксид вуглецю), тис. т

\begin{tabular}{|c|c|c|c|c|c|}
\hline Назва пункту & Всього & Пил & Діоксид сірки & Діоксид азоту & Оксид вуглецю \\
\hline \multirow{4}{*}{ Черкаси } & \multicolumn{5}{|c|}{2000} \\
\cline { 1 - 6 } & 16,821 & 2,971 & 5,211 & 2,407 & 2,747 \\
\cline { 2 - 6 } & 36,389 & 5,844 & 18,889 & 8,794 & 0,649 \\
\cline { 2 - 6 } & \multicolumn{5}{|c|}{2014} \\
\cline { 2 - 6 } & 29,826 & 5,905 & 12,625 & 8,702 & 0,584 \\
\cline { 2 - 6 } & 23,845 & 0,003 & 5,962 & 9,854 & 0,662 \\
\cline { 2 - 6 } & & \multicolumn{5}{|c|}{2016} \\
\hline
\end{tabular}

Постійні спостереження за станом атмосферного повітря в м. Черкаси здійснюються Черкаським обласним центром з гідрометеорології. Лабораторією спостережень за забрудненням атмосферного повітря Черкаського обласного центру гідрометеорології, який має три пости спостереження у м. Черкаси, у 2016 р. контролювалось 4 основних і 14 специфічних полютантів, включаючи важкі метали та бенз/а/пірен. Високе забруднення (вище 5 ГДК максимально разової) у 2016 р. у місті не було зафіксовано. Для розрахунку комплек- 
сного індексу забруднення атмосфери (I3А) міста в 2016 р. використовувались п'ять найбільш важливих домішок: пил, діоксид азоту, аміак, формальдегід, оксид вуглецю. За 2016 р. ІЗА становив 5,5 (за 2015 р. - 5,72), що вважається приблизно рівним середньому забрудненню атмосферного повітря $(5<\mathrm{I} 3 \mathrm{~A}<8)$.

За даними Державної установи «Черкаський обласний лабораторний центр Міністерства охорони здоров'я України» 3 метою здійснення моніторингу забруднення атмосферного повітря лабораторним центром у 2016 р. проведено дослідження на маршрутних та пересувних (підфакельних) точках, а також на межі санітарно-захисних зон промпідприємств, у межах житлової забудови, поблизу вуличних магістралей, 3 них у 150 $(2,1 \%)$ пробах виявлено перевищення гранично допустимих концентрацій забруднюючих речовин [9].

В основному зареєстровані перевищення гігієнічних нормативів за вмістом формальдегіду (13\%), оксиду вуглецю $(4,1 \%)$, діоксиду азоту $(0,1 \%)$, сірководню $(3,9 \%)$, аміаку $(1,2 \%)$, пилу $(0,85 \%)$.

У структурі загальної захворюваності населення все більшої уваги набувають хвороби, пов'язані з техногенним забрудненням атмосферного повітря. За даними Комунального закладу «Черкаський обласний інформаційно аналітичний центр медичної статистики», у 2016 р.відмічається зниження показника загальної захворюваності населення на $1,1 \%$ та збільшення показника первинної захворюваності населення на 2,1 \% [10].

У структурі загальної захворюваності всього населення переважають хронічні хвороби (системи кровообігу, органів дихання, органів травлення, кістково-м'язової та сечостатевої системи). Хвороби органів дихання займають друге рангове місце в структурі загальної захворюваності всього населення (у 2016 p. - 19,2\%, y 2015 p. - 18,2\%, у 2014 p. $18,5 \%$ ) та перше рангове місце у структурі первинної захворюваності всього населення (у 2016 p. $-44,8 \%$, у 2015 p. $-42,9 \%$, у 2014 p. 43,4\%). Показник первинної захворюваності дітей віком до 17 років становив: у 2014 р. 15669 (на 10 тис. населення); в 2015 р. - 15149 (на 10 тис. населення); у 2016 р. - 15299 (на 10 тис. населення) [8].

Визначення ризику захворюваності населення, що проживає у місцях небезпечного забруднення атмосферного повітря, дає мож- ливість прогнозувати ймовірність порушень здоров'я при різних сценаріях його впливу та встановлювати першочерговість і пріоритетність заходів щодо управління чинниками ризику на індивідуальному та загальному рівнях.

Метою роботи $\epsilon$ проведення аналізу $\mathrm{i}$ оцінювання ризику виникнення захворювань від впливу забруднення атмосферного повітря на прикладі м. Черкаси 3 використанням міжнародної методології.

Матеріали та результати досліджень. Схема аналізу ризику для здоров'я людини запропонована Американським агентством 3 охорони навколишнього середовища (USEPA) [11]. Міжнародна методологія була адаптована до умов України і викладена в методичних рекомендаціях «Оцінка ризику для здоров'я населення від забруднення атмосферного повітря» МР 2.2.12-142-2007 (наказ № 184 MO3 України від 13.04.07). Повна схема оцінки ризику передбачає проведення чотирьох взаємопов'язаних етапів: ідентифікації небезпеки; оцінювання експозиції; характеристики небезпеки (оцінювання залежності «доза-відгук»); характеристики ризику [12].

Першим етапом процедури оцінювання екологічного ризику є ідентифікація джерел можливої небезпеки повітряному басейну. Сутність цього етапу полягає у виявленні найбільш небезпечних промислових об'єктів 3 точки зору їх впливу на стан здоров'я населення.

Розглядаючи м. Черкаси як промислове місто, можна виділити ряд підприємств, які забруднюють атмосферне повітря, тим самим шкодячи здоров'ю людей. Серед таких підприємств основними забруднювачами атмосферного повітря міста є: ПАТ «Черкаське хімволокно» 3 валовим викидом 18,2 тис. т, що на 5,98 тис. т менше, ніж у 2015 р., та ПАТ «Азот» 3 валовим викидом 4,8 тис. т, що на 1,3 тис. т більше, ніж у 2015 р. Загальний викид від цих підприємств становив у 2016 р. 23 тис. т забруднюючих речовин, що становить $96 \%$ від викидів забруднюючих речовин в атмосферне повітря, які здійснювалися стаціонарними джерелами міста.

Наступним кроком у процедурі оцінювання ризику $є$ оцінювання експозиції. Оцінювання експозиції полягає у вимірюванні або визначенні частоти, тривалості і шляхів дії забруднюючих речовин, що знаходяться в навколишньому середовищі, на організм лю- 
дини. Маршрут дії, який описує рух хімічної речовини від джерела іiї надходження в природне середовище до індивідуума, що піддається дії, є обов'язковою складовою частиною будь-якого сценарію експозиції. Існує три типи експозиційного маршруту: пероральний, інгаляційний, шкірна абсорбція. Визначаючи ризик впливу атмосферного повітря на здоров'я людей, можна констатувати, що забруднюючі речовини потрапляють до організму інгаляційним шляхом, тобто в процесі дихання через легені. Наслідки дії порогових забруднювачів можуть з'являтися через декілька днів, тижнів, місяців, років або безпосередньо після дії першої дози забруднювача. Короткочасні дії тривають близько 0,5-1,0 години і викликають гостру реакцію. Тривалі дії забруднювачів супроводжуються хронічними захворюваннями. Під тривалими діями розуміють дії, які тривають понад 12 \% тривалості життя, тобто близько 8 років.

Оцінювання залежності «доза-відгук» це процес кількісної характеристики токсикологічної інформації і встановлення зв'язку між концентрацією забруднюючої речовини, що впливає на організм людини, і випадками шкідливих ефектів в експонованій популяції. Інтенсивне забруднення атмосферного повітря викидами забруднюючих речовин $є$ суттєвим фактором ризику виникнення та ускладнення перебігу у населення гострих і хронічних захворювань дихальних шляхів, бронхолегеневої системи, алергічних станів тощо. Доведено прямий зв'язок між інтенсивністю забруднення повітря і станом здоров'я, а також зростанням хронічних неспецифічних захворювань, зокрема таких, як атеросклероз, хвороби серця, рак легенів тощо. Забруднене повітря значно знижує імунітет.

Негативно впливає на стан здоров'я людини смог, що утворюється в повітрі міст в результаті фотохімічних реакцій забруднюючих речовин, спричинених викидами підприємств та автотранспорту. Він спричиняє сльозотечу, різь в очах, сухий кашель, нудоту, головний біль, стискання в грудях, задишку, загальну слабкість, $є$ причиною розладів функцій органів дихання.

Забруднення атмосферного повітря діоксидом сірки найчастіше призводить до виникнення таких захворювань, як хронічний i астматичний бронхіт, бронхіальна астма, емфізема легенів.
Дуже небезпечна для організму людини дія оксиду вуглецю. Наявність оксиду вуглецю в організмі стає причиною скарг (особливо у регулювальників руху) на головний біль, запаморочення, порушення сну, зниження пам'яті й уваги, задишку, біль у ділянці серця тощо.

В атмосферному повітрі м. Черкаси спостерігається перевищення середньорічних ГДК по аміаку та формальдегіду. Аміак $\left(\mathrm{NH}_{3}\right)$ - безбарвний газ 3 характерним різким запахом нашатирного спирту. При охолодженні до мінус $33,4^{\circ} \mathrm{C}$ аміак під звичайним тиском перетворюється в прозору рідину, що твердіє при мінус $77,8^{\circ} \mathrm{C}$. Розчиняється у воді, ефірі та інших органічних розчинах. Один об'єм води поглинає близько 750 об'ємів аміаку (при $20^{\circ} \mathrm{C}$ ). Корозійний для деяких металів. Ступінь токсичності - 4. Аміак майже вдвічі легший від повітря. Запах аміаку відчувається при концентрації (поріг сприйняття) більш ніж $0,5 \mathrm{Mr} / \mathrm{m}^{3}$. Смертельною вважається концентрація $250 \mathrm{мг} / \mathrm{m}^{3}$ при експозиції 60 хвилин. Дія аміаку на організм людини проявляється у пошкодженні органів дихання, очей, слизових оболонок та шкіри. Людина скаржиться на свербіж, почервоніння, опіки шкіри, різі в очах та сльозотечу, задуху, сильний кашель. У випадку попадання рідкого аміаку і його розчинів на шкіру можливе обмороження, при високих концентраціях парів аміаку - судоми.

Характеристика ризику інтегрує дані про небезпеку хімічних речовин, величину експозиції, параметри залежності «дозавідгук», отримані на усіх попередніх етапах досліджень, 3 метою кількісного і якісного оцінювання ризику, виявлення і оцінювання порівняльної значимості існуючих проблем для здоров’я людини.

Екологічний ризик від дії неканцерогенного (порогового) забруднювача оцінюється шляхом визначення коефіцієнта небезпеки (HQ), який являє собою відношення визначеної концентрації (C) забруднювача до їх референтних значень:

$$
\mathrm{HQ}=\mathrm{C} / \mathrm{RfC} \text {, }
$$

де HQ - коефіцієнт небезпеки; С - середня концентрація, мг $/ \mathrm{M}^{3}$; RfC - референтна концентрація, мг $/ \mathrm{M}^{3}$.

Залежно від значення HQ рівень ризику становить (табл. 4) [12]. 
Класифікація рівнів ризику

\begin{tabular}{|c|l|}
\hline HQ & \multicolumn{1}{|c|}{ Рівень ризику } \\
\hline$\leq 1,0$ & $\begin{array}{l}\text { Мінімальний - бажана величина ризику при проведенні оздоровчих і при- } \\
\text { родоохоронних заходів }\end{array}$ \\
\hline $1,0-10,0$ & $\begin{array}{l}\text { Середній - допустимий для виробничих умов. За впливу на все населення } \\
\text { необхідні динамічний контроль і поглиблене вивчення джерел і можливих } \\
\text { наслідків шкідливих впливів для вирішення питання про заходи щодо } \\
\text { управління ризиком }\end{array}$ \\
\hline $10,0-100,0$ & Значний - недопустимий для населення \\
\hline$\geq 100$ & $\begin{array}{l}\text { Високий - неприйняий для виробничих умов і населення. Необхідне про- } \\
\text { ведення заходів щодо усунення або зниження ризику }\end{array}$ \\
\hline
\end{tabular}

У випадку впливу кількох забруднювачів, які впливають на той самий орган, їх дія додається, і ризик визначається за індексом небезпеки (HI), який являє собою суму коефіцієнтів небезпек:

$$
\mathrm{HI}=\sum \mathrm{HQ}_{\mathrm{i}},
$$

де $\mathrm{HQ}_{\mathrm{i}}$ - коефіцієнти небезпеки для окремих компонентів суміші хімічних речовин, що впливають.

Розрахунок індексів небезпеки проводили 3 урахуванням критичних органів та систем, які зазнають негативного впливу досліджуваних речовин. Статистичний розрахунок ризиків виникнення захворювань від забруднення атмосферного повітря виконано за допомогою персонального комп'ютера 3 використанням стандартних програм пакета Microsoft Excel.

Для дослідження було використано матеріали спостережень за станом атмосферного повітря Черкаського обласного центру 3 гідрометеорології у 2017 р. На основі даних моніторингу якості атмосферного повітря на трьох стаціонарних постах спостереження забруднення (ПСЗ) з періодичністю відбору проб чотири рази на добу було визначено забруднюючі речовини, які робили найбільший внесок у забруднення атмосфери міста.

Встановили, що пріоритетними неканцерогенними хімічними речовинами $є$ пил, діоксид сірки, оксид вуглецю, діоксид азоту, сірководень, аміак. Результати контролю за якістю повітря у м. Черкаси у 2017 р. надано в табл. $5[4,5]$.

Всі речовини відносяться до неканцерогенних речовин 3 пороговим механізмом дії, які негативно впливають на органи дихання людини. Референтні концентрації при гострому та хронічному впливі визначаються 3 таблиць методичних рекомендацій «Оцінка ризику для здоров'я населення від забруднення атмосферного повітря〉 МР 2.2.12-142-2007 (наказ № 184 MO3 України від 13.04.07) (табл. 6) [1, 12].Розрахуємо індекс небезпеки для гострого та хронічного впливів для трьох мікрорайонів міста за рівнянням (2).

Результати розрахунків - сумарні індекси неканцерогенної небезпеки (НI) пріоритетних хімічних речовин - наведено в табл. 7.

Таблиця 5

Середньорічні концентрації забруднюючих речовин в атмосферному повітрі

\begin{tabular}{|c|c|c|c|c|c|}
\hline \multirow[t]{2}{*}{ Назва домішки } & \multicolumn{4}{|c|}{ Концентрація, мг/м³ } & \multirow{2}{*}{ 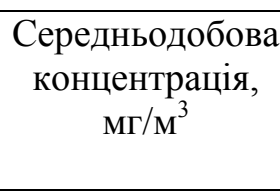 } \\
\hline & $\begin{array}{l}\text { Центр } \\
\text { міста }\end{array}$ & $\begin{array}{c}\text { Дніпровський } \\
\text { мікрорайон }\end{array}$ & $\begin{array}{c}\text { Південно- } \\
\text { Західний } \\
\text { мікрорайон }\end{array}$ & По місту & \\
\hline Пил & 0,2 & 0,2 & 0,2 & 0,2 & 0,15 \\
\hline Діоксид сірки & 0,008 & 0,010 & 0,009 & 0,009 & 0,05 \\
\hline Оксид вуглецю & 1,0 & 1,0 & 1,0 & 1,0 & 3,0 \\
\hline Діоксид азоту & 0,05 & 0,05 & 0,03 & 0,04 & 0,04 \\
\hline Сірководень & 0,001 & 0,001 & 0,001 & 0,001 & - \\
\hline Аміак & 0,05 & 0,07 & 0,04 & 0.05 & 0,04 \\
\hline
\end{tabular}


Референтні концентрації при гострому та хронічному впливі забруднювачів, які знаходяться у повітрі м. Черкаси

\begin{tabular}{|l|c|c|}
\hline \multicolumn{1}{|c|}{ Речовина } & $\mathrm{RfC}, \mathrm{Mг} / \mathrm{M}^{3}$ (гострий вплив) & $\mathrm{RfC}, \mathrm{M \Gamma} / \mathrm{M}^{3}$ (хронічний вплив) \\
\hline Пил & 0,15 & 0,05 \\
\hline Діоксид сірки & 0,66 & 0,05 \\
\hline Оксид вуглецю & 23 & 3,0 \\
\hline Діоксид азоту & 0,47 & 0,04 \\
\hline Сірководень & 0,1 & 0,002 \\
\hline Аміак & 0,35 & 0,1 \\
\hline
\end{tabular}

Таблиця 7

Сумарні індекси неканцерогенної небезпеки (НI) пріоритетних хімічних речовин

\begin{tabular}{|c|c|c|c|c|c|c|c|}
\hline \multirow[b]{2}{*}{ Мікрорайон } & \multicolumn{6}{|c|}{ Назва речовини } & \multirow[b]{2}{*}{ HI } \\
\hline & Пил & $\begin{array}{c}\text { Діоксид } \\
\text { сірки }\end{array}$ & $\begin{array}{c}\text { Оксид } \\
\text { вуглецю }\end{array}$ & $\begin{array}{c}\text { Діоксид } \\
\text { азоту }\end{array}$ & Сірководень & Аміак & \\
\hline & \multicolumn{6}{|c|}{ Гострий вплив } & \\
\hline Центр міста & 1,33 & 0,01 & 0,04 & 0,10 & 0,01 & 0,14 & 1.62 \\
\hline $\begin{array}{l}\text { Дніпровський } \\
\text { мікрорайон }\end{array}$ & 1,33 & 0,02 & 0,04 & 0,10 & 0.01 & 0,20 & 1,88 \\
\hline $\begin{array}{l}\text { Південно- } \\
\text { Західний } \\
\text { мікрорайон }\end{array}$ & 1,33 & 0,01 & 0,04 & 0,06 & 0,01 & 0,11 & 1,56 \\
\hline \multicolumn{8}{|c|}{ Хронічний вплив } \\
\hline Центр міста & 4,00 & 0,16 & 0,33 & 1,25 & 0,50 & 0,50 & 6,74 \\
\hline $\begin{array}{l}\text { Дніпровський } \\
\text { мікрорайон }\end{array}$ & 4,00 & 0,20 & 0,33 & 1,25 & 0,50 & 0,70 & 6,98 \\
\hline $\begin{array}{l}\text { Південно- } \\
\text { Західний } \\
\text { мікрорайон }\end{array}$ & 4,00 & 0,18 & 0,33 & 0,75 & 0,50 & 0,40 & 6,16 \\
\hline
\end{tabular}

Використовуючи табл. 7, робимо висновок, що в плані гострого та хронічного впливу рівень ризику - середній, але при гострому отруєнні рівень ризику в усіх мікрорайонах близький до мінімального ризику, а при хронічному отруєнні - близький до значного. Iз трьох мікрорайонів найменший рівень ризику як при гострому, так і при хронічному отруєнні спостерігається в Південно-Західному мікрорайоні, найбільший - у Дніпровському районі.

Висновки. У результаті дослідження було встановлено, що:

1. Основними забруднюючими речовинами атмосферного повітря міста Черкаси у 2017 р. є пил, діоксид сірки, оксид вуглецю, діоксид азоту, сірководень, аміак. Всі речовини відносяться до неканцерогенних сполук 3 пороговим механізмом дії, які негативно впливають на органи дихання людини.

2. Згідно 3 критеріями неканцерогенного ризику сумарний ризик для здоров'я насе- лення при вмісті шкідливих речовин у концентраціях від 0,001 до $0,200 \mathrm{Mг} / \mathrm{M}^{3}$ в атмосферному повітрі не можна вважати допустимим, оскільки існує вірогідність виникнення шкідливих ефектів у населення (захворювання органів дихання).

3. Найбільший внесок як у сумарну величину НІ, так і в ризик впливу на органи дихання при гострому і хронічному впливах має пил. Найменш вагомим у формуванні ризику є діоксид сірки.

4. Розрахований інтегральний неканцерогенний ризик для здоров'я населення при забрудненні атмосферного повітря м. Черкаси у 2017 р. можна віднести до середнього. Iз трьох мікрорайонів найменший рівень ризику як при гострому, так і при хронічному отруєнні спостерігається в Південно-Західному мікрорайоні, найбільший - у Дніпровському районі. Необхідні подальший моніторинговий контроль за якістю повітря і здійснення заходів щодо зниження ризику. 


\section{Список літератури}

1. Оцінка ризику для здоров'я населення від забруднення атмосферного повітря: Наказ MO3 України № 184 від 13.04.2007 p. URL: http://mozdocs.kiev.ua/view.php?id=6902

2. Гончаренко М. С. Екологія людини: навч. посіб. / за ред. Н. В. Кочубей. Суми: ВТД «Університетська книга»; Київ: ВД «Княгиня Ольга», 2005. 394 с.

3. Кожушко Л. Ф., Скрипчук П. М. Екологічний менеджмент: підручник. Київ: ВЦ «Академія», 2007. 432 с.

4. Управління екології та природних ресурсів Черкаської обласної державної адміністрації. Моніторинг. Стан довкілля у 2017 році. URL: eco.ck.ua/index.php? option $=$ com_content\&view $=$ article $\&$ bid $=$ 1108\&Itemid $=244$

5. Черкаси - офіційний портал міської ради. Новини. Екологія. URL: www.rada. cherkasy.ua/ua/news.php?s=18\&1=69

6. Довкілля Черкащини за 2016 рік: стат. зб. Черкаси, 2016. 160 с.

7. Екологічний паспорт Черкаської області. URL: eco.ck.ua/docs/Dop_2016

8. Регіональна доповідь про стан навколишнього природного середовища в Черкаській області у 2016 році. Черкаси, 2017. URL: eco.ck.ua/docs/Ecopasport2016.pdf

9. Державна установа «Черкаський обласний лабораторний центр Міністерства охорони здоров'я України». Соціально-гігієнічний моніторинг. Атмосферне повітря. URL: www.obles.ck.ua/index.php?option $=$ com co ntent $\&$ view $=$ categore \&layout $=$ blog $\& \mathrm{id}=\overline{59} \&$ Itemid $=79$

10. Комунальний заклад «Черкаський обласний інформаційно-аналітичний центр медичної статистики». URL: oblmedstat.ck.ua

11. US EPA. An examination of EPA risk assessment principles and practices. EPA/100/B-04/001. Washington, DC: EPA, 2004. 193 p.

12. Орел С. М., Мальований М. С., Орел Д. С. Оцінка екологічного ризику. Вплив на здоров'я людини: навч. посіб. Херсон: ОЛДІ-ПЛЮС, 2014. 232 с.

\section{References}

1. Assessment of the risk from atmospheric air pollution on public health: Decree of the Ministry of Health of Ukraine No. 184, dated April 13, 2007. URL: http://mozdocs.kiev.ua/ view.php?id $=6902$

2. Goncharenko, M. S. (2005) Human ecology: textbook / ed. by N. V. Kochubei. Sumy: VTD «Universytetska knyha»; Kyiv: VD «Kniahynia Olha», 394 p. [in Ukrainian].

3. Kozhushko, L. F. and Skrypchuk, P. M. (2007) Ecological management: textbook. Kyiv: VC «Academiya», 432 p. [in Ukrainian].

4. Department of ecology and natural resources of Cherkasy regional state administration. Monitoring. The state of the environment in 2017. URL: eco.ck.ua/index.php?option= com_content\&view $=$ article\&bid $=1108 \&$ Item id $=244$

5. Cherkasy - an official portal of the city council. News. Ecology. URL: www.rada. cherkasy.ua/ua/news.php?s=18\&1=69

6. The environment of Cherkasy region in 2016: stat. collection (2016). Cherkasy, $160 \mathrm{p}$.

7. Ecological passport of Cherkasy region. URL: eco.ck.ua/docs/Dop_2016

8. Regional report on the environmental state of Cherkasy region in 2016 (2017). Cherkasy. URL: eco.ck.ua/docs/Ecopasport 2016.pdf

9. Public institution «Cherkasy regional laboratory center of the Ministry of Health of Ukraine». Social-hygienic monitoring. Atmospheric air. URL: www.obles.ck.ua/ index.php?option $=$ com_content $\&$ view $=$ categ ore \&layout $=$ blog\&id $=\overline{59} \&$ Itemid $=79$

10. Communal institution «Cherkasy regional information-analytical center of medical statistics». URL: oblmedstat.ck.ua

11. US EPA. An examination of EPA risk assessment principles and practices (2004). EPA/100/B-04/001. Washington, DC: EPA, $193 \mathrm{p}$.

12. Orel, S. M., Malyovanyy, M. S., Orel, D. S. (2014) Assessment of environmental risk. Influence on human health: textbook. Kherson: OLDI-PLUS, 232 p. [in Ukrainian]. 
T. P. Honcharenko, Ph.D. (Chemical Sciences), associate professor, e-mail: t.p.g@inbox.lv

L. I. Zhytska, Ph.D. (Biological Sciences), associate professor e-mail: zhytska_lyudmila@ukr.net

Cherkasy State Technological University

Shevchenko blvd, 460, Cherkasy, 18006, Ukraine

\section{ANALYSIS AND ESTIMATION OF THE RISKS OF THE POPULATION DISEASE DEPENDING ON THE QUALITY OF ATMOSPHERIC AIR \\ IN THE CITY OF CHERKASY IN 2017}

The analysis of statistical information on the volumes of emissions from mobile and stationary sources of atmospheric air pollution is carried out. The assessment of complex influence of harmful substances emissions on the quality of air basin and the health of the city population is made. The reasons that lead to the accumulation of pollutants are investigated. The level of the risk of morbidity of the population of Cherkasy, living in places with dangerous pollution of atmospheric air, is calculated.

Key words: atmospheric air, emissions, concentration, pollutant, health, risk, Cherkasy.

Стаття надійшла 19.02.2018.

Рецензенти: Г. С. Столяренко, д.т.н., професор,

С. В. Голуб, д.т.н., професор. 